\title{
Empirical Research of the ISO 9001:2015 Transition Process in Portugal: Motivations, Benefits, and Success Factors
}

DOI: 10.12776/QIP.V22I2.1099

\author{
Luis Miguel Fonseca, José Pedro Domingues
}

Received: 03 April 2018

Accepted: 14 July 2018

Published: 31 July 2018

\begin{abstract}
Purpose: With the transition period for ISO 9001 certified organisations to migrate to the 2015 edition ending 15th September 2018, this investigation aims to evaluate the status of ISO 9001:2015 transition process and provide useful knowledge on the corresponding motivations, benefits, and success factors.

Methodology/Approach: An empirical study of more than 300 Portuguese organisations ISO 9001 certified, or in certification process, encompassing a wide range of activities sectors, was carried out.

Findings: As of May 2017, 19\% of the respondents already have ISO 9001:2015 certification and all the remaining one's plan to complete the process in time. The principal reported benefits are risk-based thinking, mapping of the organisational context, and stakeholder identification. Simultaneously those were the issues that required more attention and effort to be mastered and implemented. Additionally, there is evidence that ISO 9001:2015 enhances both internal and external organisational issues and generates benefits for all the researched dimensions. Based on the respondents' responses, organisations who claimed that external motivations were the primary drivers to ISO 9001:2015 implementation systematically rate higher all the benefits when compared with the rating ascribed by those organisations who claimed internal motivations. Moreover, it is possible to conclude that the perceived benefits from ISO 9001:2015 implementation and certification seem to be strongly influenced by two primary dimensions: the (smaller) organisation size and the (lesser) international presence.
\end{abstract}

Research Limitation/implication: Due to ISO 9001:2015 novelty, the results of this investigation should be subject to future confirmation and replicated in other countries to allow a generalisation of the conclusions. Since the survey is based on the perceptions of the organisation's Managers, there is a potential response bias risk that should be acknowledged. 
Originality/Value of paper: With more than 1.2 million ISO 9001 certified organisation worldwide, this a highly relevant issue both for organisations, practitioners and academics. Due to ISO 9001:2015 novelty, this investigation aims to fill this research gap.

Category: Research paper

Keywords: ISO 9001:2015; quality management systems; certification; benefits

\section{INTRODUCTION}

\subsection{The ISO 9001:2015 International Standard Edition}

ISO 9001:2015 (ISO, 2015) was published in September 2015 comprising a twofold goal: reliability- by ensuring that organizations who meet its requirements on a consistent basis provide products and services that satisfy their customers' needs and expectations addressing the relevant statutory and regulatory requirements; flexibility- by developing the 2015 edition appropriate and suitable for the present complex, demanding and dynamic business environments. According to Fonseca (2015a) some of the major new approaches of the ISO 9001:2015 are:

- A strengthened approach enabling managers to demonstrate their leadership throughout all levels of the organisation;

- A reinforced integration with the organisation's business and other management systems (MS) components;

- The consideration of the organisation's context (including its internal culture, external factors, and the requirements and expectations of the relevant stakeholders);

- The adoption of risk-based-thinking;

- The introduction of novel concepts such as organisational knowledge and change management;

- The consideration of both continual and disruptive improvement;

- The adoption of more pragmatic and non-prescriptive requirements with greater emphasis on the achievement of results and less on documentation.

As of 15th September 2018, all ISO 9001:2008 (ISO, 2008) certificates will be no longer valid. Organisations intending to comply with the requirements of the ISO 9001 certificate should transition from their existing ISO 9001:2008 Quality Management System (QMS) to the new edition, via a successful transition audit, or, in case they are not yet ISO 9001:2008 certified, to be audited and certified against the ISO 9001:2015 international standard. In both cases, either the transition process or the initial certification process should be assessed by a 
credible and recognised certification body, preferably operating under ISO 17,021 accreditation. Although still a novel theme, ISO 9001:2015 has "caught" researchers' attention as depicted in Tab. 1.

Table 1 - ISO 9001:2015 Research Summary (Authors Own Elaboration)

\begin{tabular}{|c|c|}
\hline Research conclusion & Author(s) \\
\hline $\begin{array}{l}\text { ISO } 9001: 2015 \text { is compared with Total Quality Management approaches } \\
\text { concluding it is a step towards TQM, with significant benefits for the } \\
\text { organisations, such as less emphasis on documentation and new/reinforced } \\
\text { approaches. }\end{array}$ & $\begin{array}{r}\text { Fonseca } \\
(2015 \mathrm{a})\end{array}$ \\
\hline $\begin{array}{l}\text { A stepwise ISO-based Total Quality Management implementation approach } \\
\text { based on ISO 9001:2015 is proposed. }\end{array}$ & $\begin{array}{r}\text { Chen, et al. } \\
\text { (2016) }\end{array}$ \\
\hline $\begin{array}{l}\text { Based on an empirical worldwide study among IRCA registered auditors the } \\
\text { authors concluded that ISO 9001:2015 with the adoption of the Annex SL, } \\
\text { common high-level structure for MSs, and the adoption of identical core } \\
\text { context, common terms, and definitions, favours integration with other MSs } \\
\text { such as the ISO 14001:2015- Environment MS. }\end{array}$ & $\begin{array}{r}\text { Domingues, et } \\
\text { al. (2016) }\end{array}$ \\
\hline $\begin{array}{l}\text { The authors propose a model for integrating Lean or Six Sigma projects by } \\
\text { systematical linkage with the applicable clauses and sub-clauses of ISO } \\
9001: 2015 \text {. }\end{array}$ & $\begin{array}{r}\text { Marques, et al. } \\
\text { (2016) }\end{array}$ \\
\hline $\begin{array}{l}\text { Based on a survey of } 393 \text { IRCA registered auditors worldwide, the authors } \\
\text { conclude that ISO 9001:2015 is in line with modern business and quality } \\
\text { management concepts and will be a useful tool for the companies. }\end{array}$ & $\begin{array}{r}\text { Fonseca and } \\
\text { Domingues } \\
(2017)\end{array}$ \\
\hline $\begin{array}{l}\text { By analysing ISO } 9001: 2015 \text { and gathering feedback during the first six } \\
\text { months of its application, the authors consider that there are improvements } \\
\text { such as the new harmonized structure, the adoption of risk-based thinking } \\
\text { and the reinforced business-centred focus on business processes. However, } \\
\text { they claim that ISO } 9001: 2015 \text { is generally ambiguous and encompasses } \\
\text { some incomplete and imperfect text and requirements. }\end{array}$ & $\begin{array}{r}\text { Anttila and } \\
\text { Jussila (2017) }\end{array}$ \\
\hline $\begin{array}{l}\text { Based on an empirical study amidst } 1175 \text { German companies the authors } \\
\text { point out that there is a lack of training and knowledge concerning the ISO } \\
9001: 2015 \text { new requirements particularly concerning the adoption of "risk- } \\
\text { based thinking". }\end{array}$ & $\begin{array}{r}\text { Rybskia, et al. } \\
\text { (2017) }\end{array}$ \\
\hline $\begin{array}{l}\text { Given the new ISO 9001:2015 requirements, a survey was held amidst ISO } \\
9001 \text { certified organisations, to ascertain the competencies demanded today } \\
\text { for Quality and Organizational Excellence Managers. The results highlight } \\
\text { that "the knowledge of culture and the organisational process" is the most } \\
\text { highly required competency and skill for these professionals. }\end{array}$ & $\begin{array}{r}\text { Fonseca, } \\
\text { Domingues and } \\
\text { Sá (2017) }\end{array}$ \\
\hline
\end{tabular}

To sum up, on the one hand, there is a stream of authors that regard the ISO 9001:2015 standard a valuable step towards TQM. Concurrently, these authors consider that the last revision of the ISO 9001 standard favours the integration with other management disciplines. Conversely and on the other hand, there is a stream of authors that acknowledge the ISO 9001:2015 benefits but also some shortcomings. Furthermore, some authors point out that there is a lack of awareness and training on ISO 9001:2015. This research study aims to tighten 
this research gap, by gathering empirical knowledge (to formulate grounded theoretical propositions) on the ISO 9001:2015 transition and certification phenomenon, notably the approaches adopted by the organisations that proceeded with the transition, the significant benefits attained and the obstacles faced throughout this process. With more than 1.2 million ISO 9001 certified organisation from all sectors of activity, worldwide (ISO, 2017), this is a relevant issue both for organisations, practitioners and academics and due to ISO 9001:2015 novelty, empirical investigations are still scarce.

\subsection{Motivations and Benefits of ISO 9001 Certification}

Researchers have paid significant attention to the ISO 9001 certification phenomenon focusing on the motivations for its implementation and certification and the achieved benefits. Tab. 2 presents a summary of the more relevant studies addressing this research topic and the soundest conclusions.

Table 2 - ISO 9001 Certification Research Synthesis (Authors Own Elaboration)

\begin{tabular}{|c|c|}
\hline Dimension & Conclusions/Authors \\
\hline \multirow[t]{3}{*}{$\begin{array}{l}\text { Benefits of the ISO } 9001 \\
\text { certification }\end{array}$} & $\begin{array}{l}\text { Positive results due to ISO } 9001 \text { implementation and } \\
\text { certification: Bernardo, et al. (2015); Boiral and Amara } \\
\text { (2009); Heras, et al. (2002); Martínez-Costa and Martínez- } \\
\text { Lorente (2007); Martínez-Costa, et al. (2009); Poksinska } \\
\text { and Dahlgaard (2003); Psomas (2013); Sampaio, Saraiva } \\
\text { and Rodrigues (2009); Tari, Molina-Azorin and Heras } \\
\text { (2012), Fonseca, et al. (2017). }\end{array}$ \\
\hline & $\begin{array}{l}\text { Emphasis on positive internal results such as organizational } \\
\text { and operational improvements: Calvo, et al. (2016); } \\
\text { Martínez-Costa, Martínez-Lorente and Choi (2008); } \\
\text { Terziovski and Power (2007); Wahid and Corner (2009). }\end{array}$ \\
\hline & $\begin{array}{l}\text { Emphasis on positive external results, e.g., better brand } \\
\text { image, improved customer relationships; more favourable } \\
\text { market position of the company; access to markets; } \\
\text { financial benefits, strengthening of relationships in } \\
\text { distribution channels and improve logistics: Benner and } \\
\text { Veloso (2008); Corbett, Montes and Kirsch (2005); Dick, } \\
\text { Heras and Casadesús (2008); Martínez-Costa and Martínez- } \\
\text { Lorente (2003, 2007); Sharma (2005); Terlaak and King } \\
\text { (2006), Zimon, Gajewska and Bednárová (2017). }\end{array}$ \\
\hline \multirow[t]{2}{*}{$\begin{array}{l}\text { The emphasis of the } \\
\text { internal/external type of } \\
\text { motivation for the } \\
\text { implementation and certification } \\
\text { of ISO 9001 }\end{array}$} & $\begin{array}{l}\text { Emphasis on external motivations such as regulations for } \\
\text { market access; customer demands; pressure from } \\
\text { competitors; access to government incentives: Bhuiyan and } \\
\text { Alam (2010); Heras and Arana (2006); Martínez-Costa, } \\
\text { Martínez-Lorente and Choi (2008); Terziovski, Power and } \\
\text { Sohal (2003). }\end{array}$ \\
\hline & $\begin{array}{l}\text { Emphasis on internal motivations lead organisations to } \\
\text { implement and certify their QMS to achieve internal and } \\
\text { external benefits: Calvo, et al. (2016); Chang and Lo }\end{array}$ \\
\hline
\end{tabular}




\begin{tabular}{|c|c|}
\hline \multirow[t]{2}{*}{ Dimension } & Conclusions/Authors \\
\hline & $\begin{array}{l}\text { (2005); Fotopoulos and Psomas (2010); Llopis and Tari } \\
\text { (2003); Willar, Coffey and Trigunarsyah (2015), Castillo- } \\
\text { Peces, et al. (2017). }\end{array}$ \\
\hline $\begin{array}{l}\text { Influence of the internal/external } \\
\text { type of motivation for the } \\
\text { implementation of the ISO } 9001 \\
\text { on achieving positive results }\end{array}$ & $\begin{array}{l}\text { Internal motivations to implement ISO } 9001 \text { can foster } \\
\text { organisational and process improvements which may } \\
\text { contribute to better quality and customer satisfaction, } \\
\text { leading to improved financial performance, and } \\
\text { competitive position. External motivation contributes to } \\
\text { better access to markets and image enhancement, but if no } \\
\text { internal improvements are implemented, the external } \\
\text { benefits might not endure: Boiral and Roy (2007); Llopis } \\
\text { and Tari (2003); Martínez-Costa, Martínez-Lorente and } \\
\text { Choi (2008); Prajogo (2011); Sampaio, Saraiva and } \\
\text { Rodrigues (2009). }\end{array}$ \\
\hline $\begin{array}{l}\text { The impact of the organization } \\
\text { sector of activity on the positive } \\
\text { benefits of ISO } 9001 \text { certification }\end{array}$ & $\begin{array}{l}\text { There are observed differences in the driving forces for ISO } \\
9001 \text { certification between manufacturing and services: } \\
\text { Pekovic (2010). }\end{array}$ \\
\hline \multirow[t]{2}{*}{$\begin{array}{l}\text { Influence of the organization size } \\
\text { on the positive benefits of ISO } \\
9001 \text { certification }\end{array}$} & $\begin{array}{l}\text { It is more difficult to SME's because those organizations } \\
\text { have fewer relevant resources than larger ones: Gustafsson, } \\
\text { et al. (2001); Ismyrlis and Moschidis (2015). }\end{array}$ \\
\hline & $\begin{array}{l}\text { Size is not relevant, since SME's are more flexible and } \\
\text { open to change than larger ones, and the start point might } \\
\text { be lower: Briscoe, Fawcett and Todd (2005); Lee, To and } \\
\text { Yu (2009); Prado, et al. (2013); Fotopoulos and Psomas, } \\
\text { (2010); Terziovski, Power and Sohal (2003). }\end{array}$ \\
\hline $\begin{array}{l}\text { The impact of the organization } \\
\text { international presence intensity } \\
\text { on the positive benefits of ISO } \\
9001 \text { certification }\end{array}$ & $\begin{array}{l}\text { Some research shows a positive relationship between } \\
\text { export intensity (the ratio of export sales to total sales) and } \\
\text { firm performance, since firms with a higher rate of export } \\
\text { must be more effective and efficient (Bernard and Jensen, } \\
\text { 1999; Ling-Yee, 2004), and have access to more } \\
\text { knowledge, therefore becoming more competitive (Ellis, } \\
\text { Davies and Wong, 2011). }\end{array}$ \\
\hline \multirow[t]{2}{*}{$\begin{array}{l}\text { Influence of number of years of } \\
\text { the certification on the positive } \\
\text { effects of ISO } 9001 \text { certification }\end{array}$} & $\begin{array}{l}\text { The benefits of the implementation and certification of an } \\
\text { ISO 9001 QMS need time to be achieved and growth with } \\
\text { the number of years since certification: Corbett, Montes } \\
\text { and Kirsch (2005); Fonseca (2015b); Martínez-Costa, } \\
\text { Martínez-Lorente and Choi (2008); Terziovski and Power } \\
\text { (2007); Wilson, Walsh and Needy (2003), Castillo-Peces, } \\
\text { et al. (2017) }\end{array}$ \\
\hline & $\begin{array}{l}\text { Time is not significant, and the benefits of certification may } \\
\text { even decrease with time: Casadesus and Karapetrovic } \\
\text { (2005); Casadesus, Karapetrovic and Heras (2004); } \\
\text { Karapetrovic, Fa and Heras (2010); Sampaio, Saraiva and } \\
\text { Rodrigues (2009). }\end{array}$ \\
\hline $\begin{array}{l}\text { Influence on the intensity of } \\
\text { Quality } \\
\text { methodologies application (such }\end{array}$ & $\begin{array}{l}\text { There are synergies between Six Sigma and ISO 9001: } \\
\text { Pfeifer, Reissiger and Canales (2004); Lupan, et al. (2005); } \\
\text { Dey (2010). }\end{array}$ \\
\hline
\end{tabular}




\begin{tabular}{|l|l|}
\hline \multicolumn{1}{|c|}{ Dimension } & \multicolumn{1}{|c|}{ Conclusions/Authors } \\
\hline $\begin{array}{l}\text { as Lean, Kaizen, 6 Sigma) to } \\
\text { maximize ISO 9001 certification } \\
\text { benefits }\end{array}$ & $\begin{array}{l}\text { There is a potential role of the Lean principles and tools } \\
\text { and principles under the requirements of ISO 9001:2008 } \\
\text { clauses. There are synergies between the ISO 9001 } \\
\text { requirements and improvement Kaizen events and the } \\
\text { application of structured Lean tools: Chiarini (2011); } \\
\text { Micklewright (2010). }\end{array}$ \\
\hline
\end{tabular}

With the introduction of the ISO 9001:2015 new approaches, when compared to the ISO 9001:2008 version, it is advisable to investigate where we stand concerning the motivations, benefits, and success factors for ISO 9001:2015 certification. Moreover, as the three-year transition for ISO 9001 will end 15th September 2018, the Accreditation Forum (IAF) that supersedes the developing of principles and practices for the conduct of conformity assessment, passed a resolution that as of 15th March 2018, conformity assessment bodies must conduct all ISO 9001 audits to the new version ISO 9001:2015 (IAF, 2017). With estimates that more than $50 \%$ of ISO 9001 certified organisations still didn't complete the transition at the end of 2017 (informal survey carried by the authors within ISO 9001 certification bodies), the results of this investigation can be of value to understand and support the ISO 9001:2015 transition process.

\section{METHODOLOGY}

The research started with the review of the published studies addressing ISO 9001:2015, its benefits and shortcomings and previous studies concerning ISO 9001 certification (motivations, benefits and organisational dimensions that influence its outcomes). Due to ISO 9001:2015 novelty, there are limited empirical studies on its implementation and certification, which lead to the proposal of the following research questions (RQ):

$R Q$ 1: Halfway through the transition period, what is the status concerning ISO 9001:2015 transition and certification?

$R Q$ 2: What are the main benefits achieved with ISO 9001:2015 implementation and certification?

$R Q$ 2.1: Are there significant differences between Quality Managers and CEOs?

$R Q$ 3: What are the new ISO 9001:2015 themes that your organisation considers most difficult to implement successfully?

$R Q$ 3.1: Are there significant differences between organisations that have already been certified and those have not yet done it?

RQ 4: What are the main dimensions that influence the successful ISO 9001:2015 implementation and certification? 
$R Q$ 4.1: Does the internal/external type of motivation to implement ISO 9001:2015 influence the achievement of positive results?

$R Q$ 4.2: Does the organisational sector influences the achievement of positive results with ISO 9001:2015 implementation and certification?

$R Q$ 4.3: Does the organisation size influence the achievement of positive results with ISO 9001:2015 implementation and certification?

$R Q$ 4.4: Does the organisation international presence intensity impact on the achievement of positive results with ISO 9001:2015 implementation and certification?

$R Q$ 4.5: Does the number of year of the organisation certification influence the achievement of positive results?

Quantitative research, supported on a survey online was adopted, with a structure similar to Fonseca and Lima (2015), where construct reliability was tested and validated with Cronbach Alpha (greater than 0.7).

The collection of data to address these research questions were supported by in an online survey that was carried out for three weeks, throughout April and May 2017, among organisations ISO 9001 certified or in certification process by the leading Portuguese certification body (APCER, 2017).

The online survey is a suitable research technique widely adopted to reach a restricted population. This technique is particularly appropriate in the context of this study characterised by scarce resources and the need for fast response time. The participants could access their survey via an individual link sent per mail. The survey structure encompassed 4 primary group of questions addressing the following central themes: organisation characterization, ISO 9001:2015 certification/transition, internal/external certification motivation (Likert 1Totally Internal to 7- Totally External scale), certification benefits (8 items based on literature review, assessed through a Likert Scale: 1- No relevance to 5Totally Relevant) and respondent data. The statistical analysis and statistical hypotheses testing were supported by the use of IBM SPSS Statistics 23 software. Both the Chi-square and the Wilcoxon signed ranks statistical test were adopted throughout the results analysis.

The survey results were monitored during the survey period to check for possible non-respondent bias using "wave analysis" to compare the results from late respondents and early respondents (Armstrong and Overton, 1977). Since no significant differences were found, we can assume that non-respondents' responses would be similar, minimising the possible bias error. Additionally, the analysis of the survey results suggests that it is representative since the distribution of the sample is consistent with the population. 


\section{RESULTS AND DISCUSSION}

\subsection{Characterization of the Respondent Companies}

The survey yielded a total of 310 valid responses (response rate 18\%). Concerning the sector of activity, industry accounted for nearly $38 \%$ of the survey responses, commerce $(11 \%)$ and services (51\%). These results assure a well-balanced sample of service-oriented and producing businesses for this research, as depicted in Fig. 1.

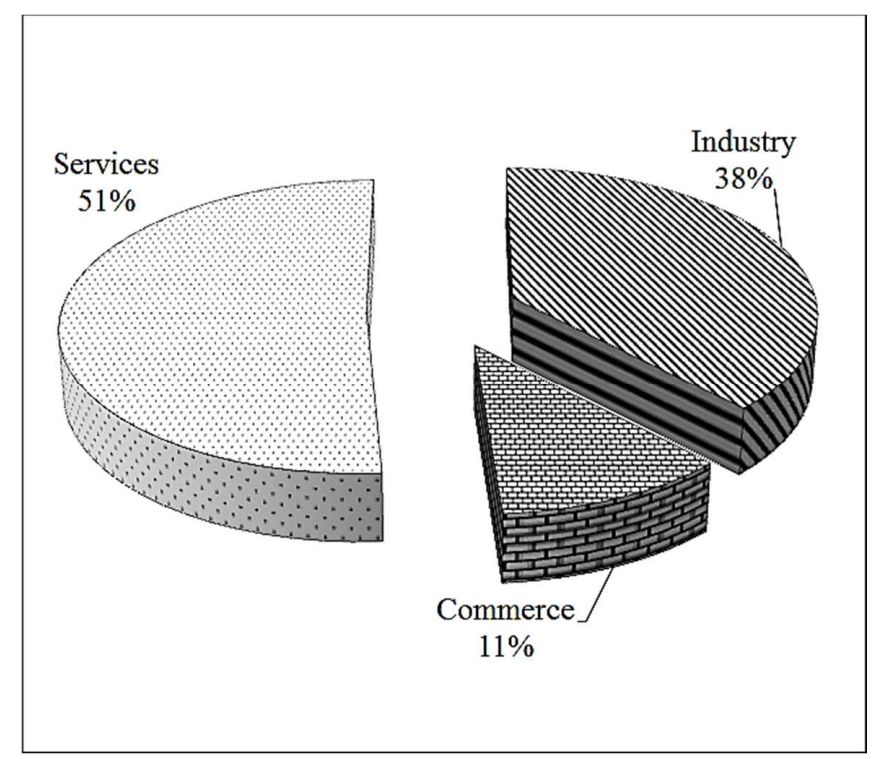

Figure 1 - Respondent Companies - Breakdown by Sector of Activity (Authors Own Elaboration)

Respondents were mainly quality managers $(80 \%)$, followed by CEOs $(11 \%)$ and other quality management collaborators (8\%), as one may observe in Fig. 2. 


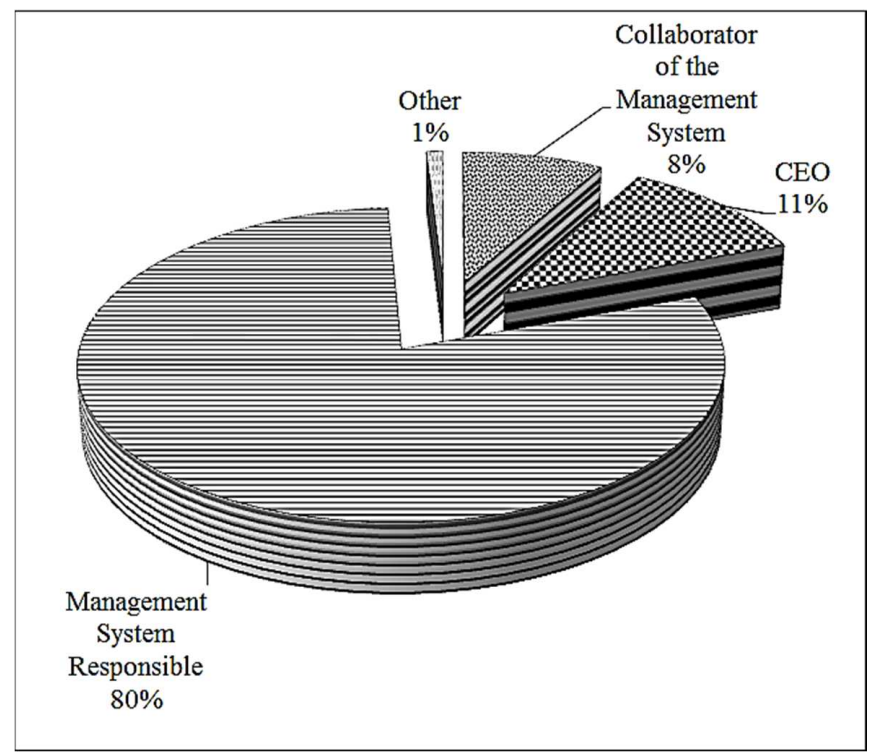

Figure 2 - Respondent Companies - Breakdown by Organisational Function (Authors Own Elaboration)

As depicted in Fig. 3, most organisations operate in the internal market (41\%), while $36 \%$ have some international presence (less than $25 \%$ of total revenue) and $23 \%$ are more internationalised (more than $25 \%$ total revenue).

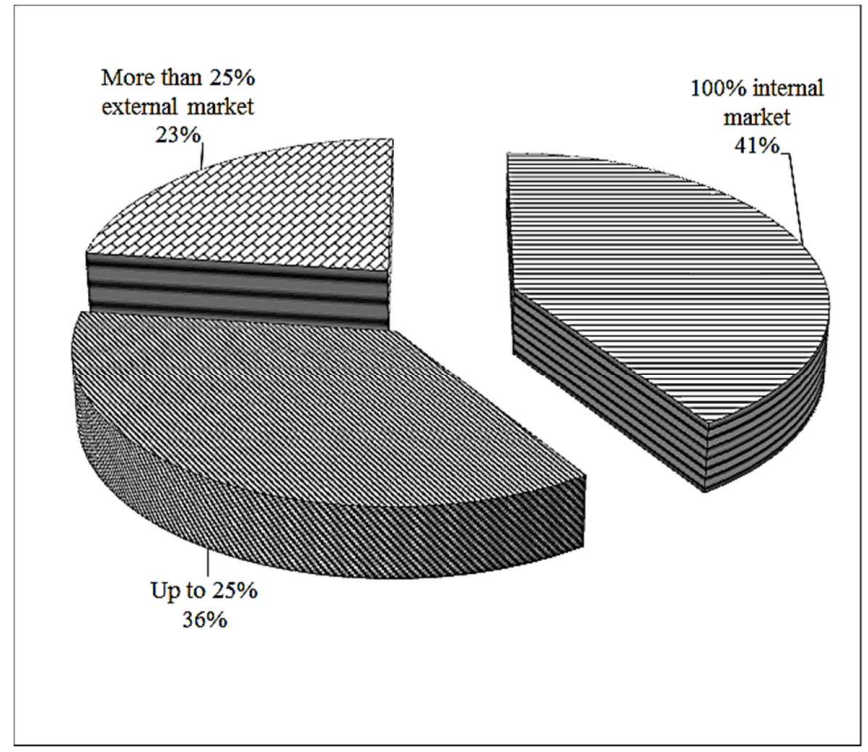

Figure 3 - Respondent Companies - Breakdown by the International Export Intensity

(Authors Own Elaboration) 
Concerning the number of employees, $62 \%$ of the respondent organisations employ less than 50 collaborators and $31 \%$ employ between 50 and 250 collaborators. Solely $6 \%$ of the organisations have more than 250 employees (Fig. 4). These results are aligned with the Portuguese profile of the certified companies which is characterised mainly by a high density of SMEs.

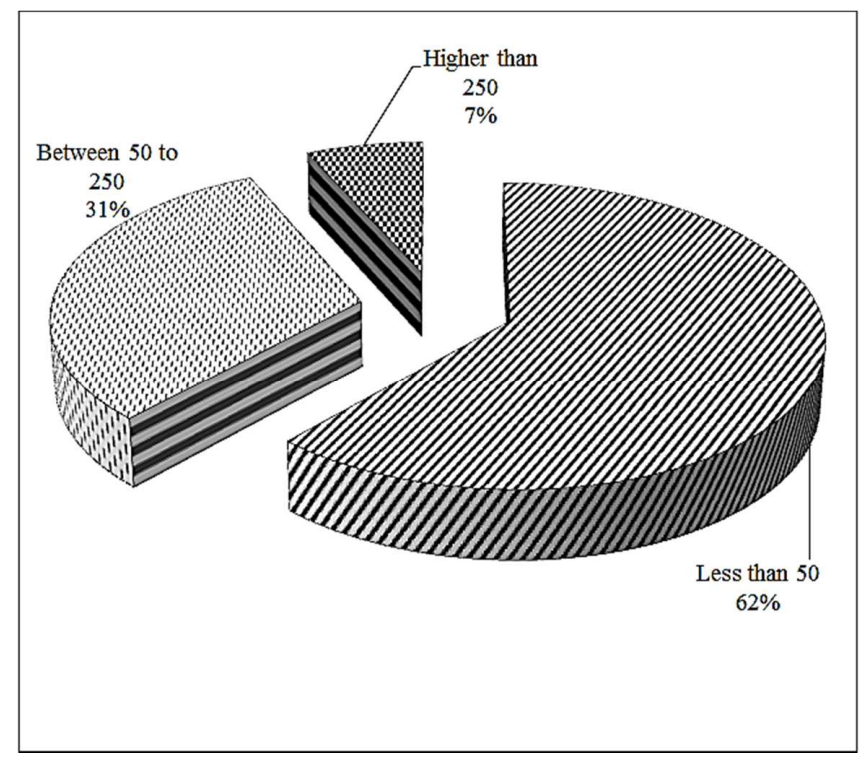

Figure 4-Respondent Companies - Breakdown by the Number of Employees

(Authors Own Elaboration)

Concerning the distribution of the number of years the organisations have implemented their QMSs, it shows a balanced distribution concerning the QMS years since its implementation and is in line with the population distribution suggesting that the sample accurately matches the population (Fig. 5). 


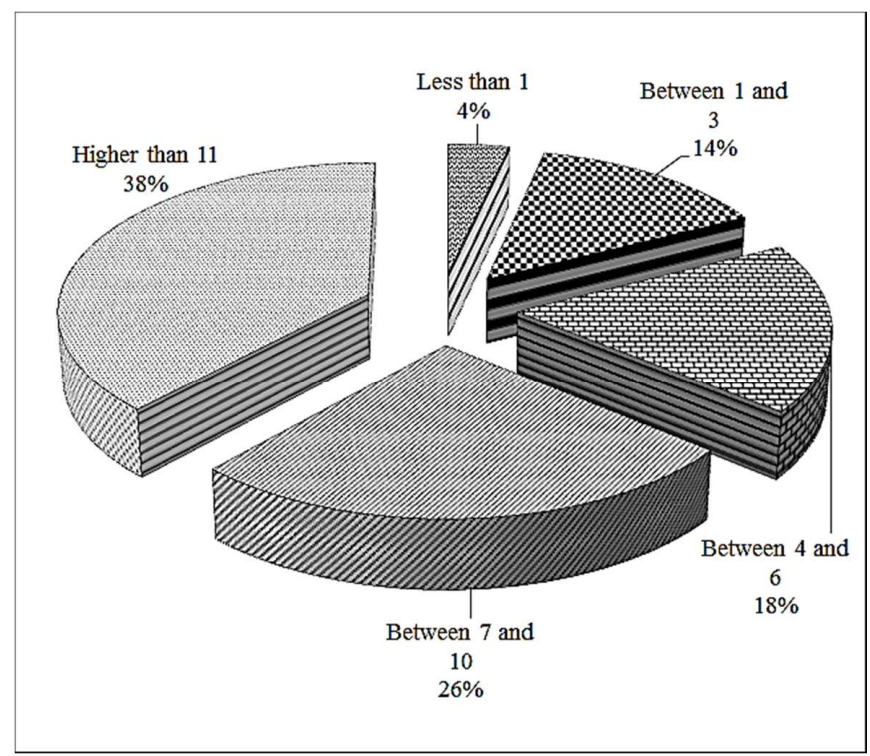

Figure 5 - Respondent Companies - Breakdown by the Number of Years Since the Implementation of the QMS (Authors Own Elaboration)

\subsection{Study on ISO 9001:2015 Transition/Certification}

Concerning the research question 1 (Halfway through the transition period, what is the status concerning ISO 9001:2015 transition and certification?), as shown in Fig. 6, by May 2015 20\% of the respondents were indeed certified accordingly the ISO 9001:2015 (either by transitioning from ISO 9001:2018 or direct certification with ISO 9001:2015) and 79\% mentioned the desire to proceed with the transition to ISO 9001:2015.

From the 72 organisations that proceeded with the transition, 58\% made only minor adjustments to their QMS, while $37 \%$ made a full a substantial reformulation. Concerning the 238 organisations that have not yet completed the transition/certification to ISO 9001:2015 they plan to do it throughout 2017 (46\%) and 2018 (52\%) (Fig. 8) and stressed that they are in the process of studying the ISO 9001:2015 international standard (39\%) or lacked time to do it (36\%). However, as one may observe both in Fig. 7 and 8, the rate of transition increased $64 \%$ in the first four months of 2017 , when compared to 2016, and approximately half of the organisations plan to proceed with the transition in 2017, and the other half throughout 2018 (Fig. 8). 


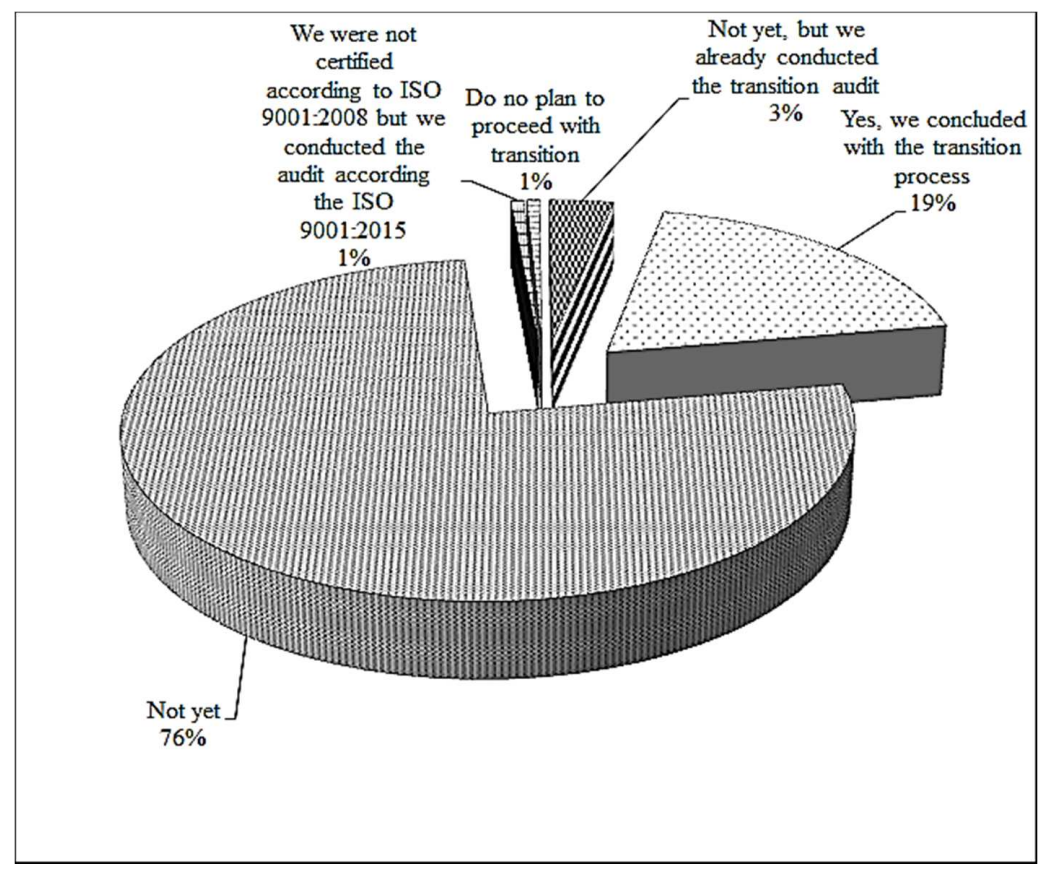

Figure 6 - Respondent Companies - Status Concerning ISO 9001:2015 Transition/Certification (Authors Own Elaboration)

These results suggest that the transition rate is growing and (by May 2017) almost all organisations plan to proceed with it till 15 September 2018. The organizations which proceed with the transition to the novel ISO 9001:2015 relied mainly on external consultants $(57 \%)$ and training (47\%); however, among those organizations that have not yet completed the ISO 9001:2015 transition/certification some are still trying to master the international standard $(40 \%)$ and others reported lack of time to do it successfully (37\%). From the 72 organisations that proceeded with the transition, 58\% made only minor adjustments to their QMS, while 37\% made a full a substantial reformulation. 


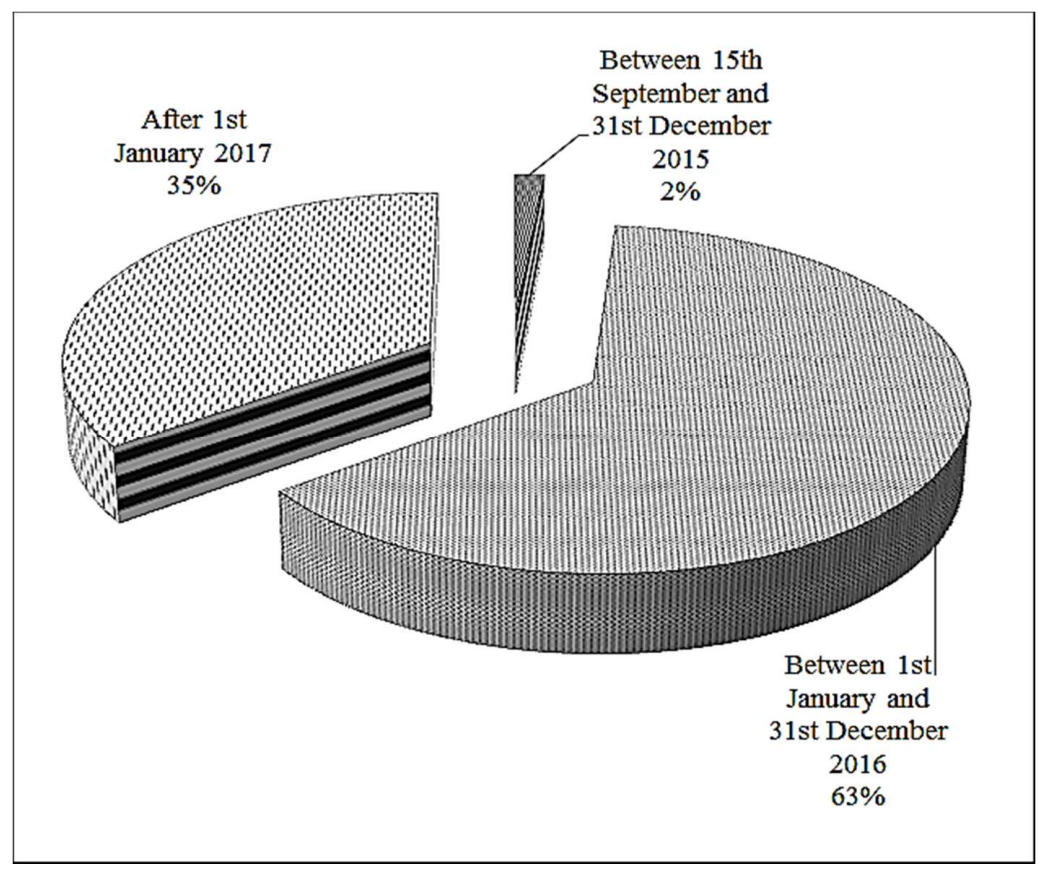

Figure 7 - Status Concerning ISO 9001:2015 Transition/Certification - Breakdown by Date of Completion (Authors Own Elaboration)

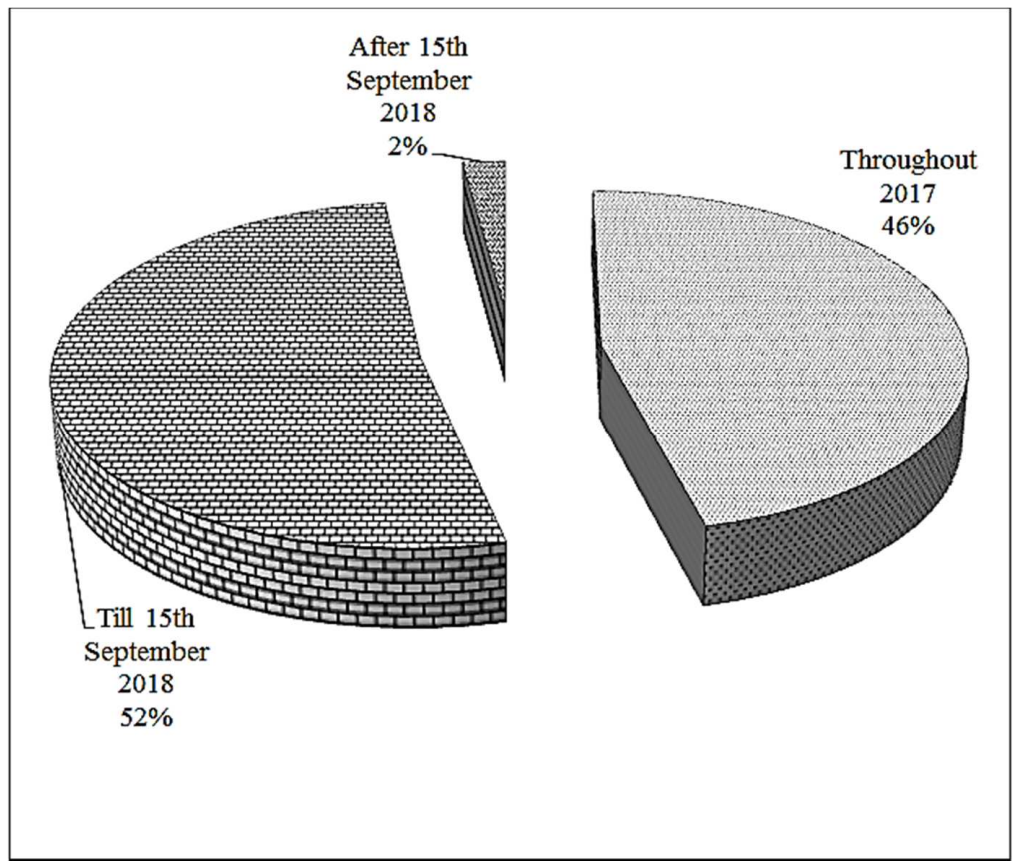

Figure 8-Organizations Still in Transition Process - Breakdown by the Planned Deadline for the ISO 9001:2015 Certification (Authors Own Elaboration) 
Based on the results collected, five new ISO 9001:2015 themes were identified as the most beneficial ones:

- Risk and opportunities determination and adoption of risk-based thinking;

- Organizational context determination - internal and external relevant issues;

- Determination of the relevant stakeholders and their relevant requirements;

- Organisational knowledge;

- Change control.

Research question 2.1 aims to evaluate if there are there significant differences concerning ISO 9001:2015 main benefits, between the Quality Managers and the CEOs. The graphical depiction of the summarized results (Fig. 9) suggests three main themes as those that experienced the most beneficial evolution upon the ISO 9001:2015 implementation: Risk and opportunities determination and adoption of risk-based thinking, determination of the relevant stakeholders and their relevant requirements and the organizational context determination- internal and external relevant issues. One should stress that both CEOs and Quality Managers pointed out these same three beneficial themes over the others.

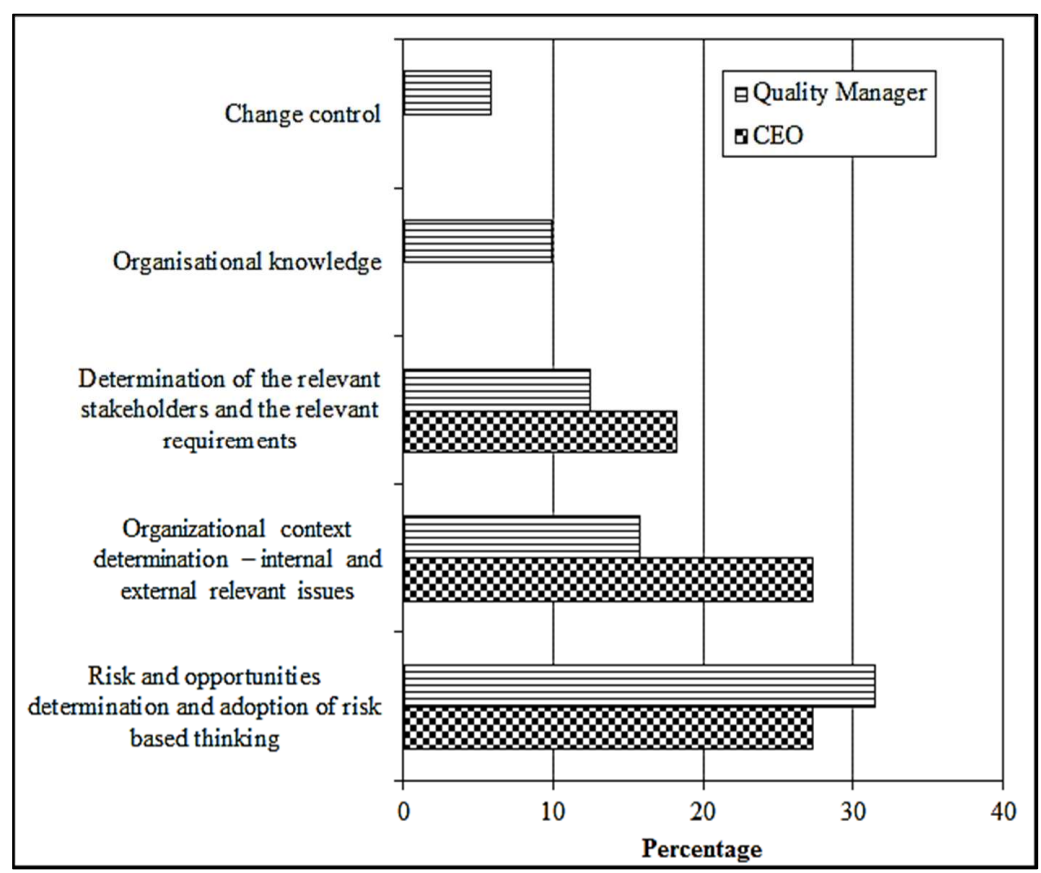

Figure 9 - Relative Distribution of the Most Often Reported Beneficial Themes Collected Upon ISO 9001:2015 Implementation

- Breakdown by CEOs and Quality Managers (Authors Own Elaboration) 
To statistically assess if a significant difference does exist among the perceptions expressed by the CEOs and those expressed by quality managers the Chi-Square statistical test was conducted. The p-value (0.619) suggests that based on the collected results there is no evidence of statistical differences between the two groups (Tab.3), however, due to the small CEOs sample size, their results need to be considered with caution.

Table 3 - Chi-Square Tests (Authors Own Elaboration)

\begin{tabular}{|l|r|r|r|r|}
\hline & \multicolumn{1}{|c|}{ Value } & df & $\begin{array}{c}\text { Asymptotic Significance } \\
\text { (2-sided) }\end{array}$ & \multicolumn{1}{c|}{$\begin{array}{c}\text { Exact Sig. } \\
\text { (2-sided) }\end{array}$} \\
\hline Pearson Chi-Square & $29.967^{\mathrm{a}}$ & 33 & 0.619 & 0.694 \\
\hline Likelihood Ratio & 30.510 & 33 & 0.592 & 0.580 \\
\hline Fisher's Exact Test & 33.740 & & & 0.360 \\
\hline N of Valid Cases & 62 & & & \\
\hline
\end{tabular}

Concerning the research question 3 "What are the new ISO 9001:2015 themes that your organisations consider most difficult to successfully implement?" the summarized results are depicted in Fig. 10. These results (breakdown by companies already certified and not yet certified) concerning the most difficult themes to be implemented (or the themes expected to be most difficult to implement) suggest that both the organizations that proceeded with the transition to the ISO 9001:2015 and those that did not point out the "Risk and opportunities determination and adoption of risk-based thinking" as the theme presenting more challenges to implement. Additionally, the "Determination of the relevant stakeholders and their relevant requirements" and "Organizational context determination- internal and external relevant issues" are mentioned by both groups as other themes indeed difficult to implement (companies that proceeded with the transition) or expected to be difficult to implement (companies that not yet proceeded with the transition).

To answer research question 3.1 "Are there significant differences concerning the ISO 9001:2015 most difficult themes, between organisations already certified with ISO 9001:2015 and those that have not yet done it?", the Chi-Square statistical test was adopted to ascertain statistical differences between the distributions of the two groups. The p-value suggests that based upon the collected results there is no evidence of statistical differences between the two groups, i.e., the expected difficulties to be faced during the implementation process are in fact those that are experienced by the companies that proceeded with the transition. 


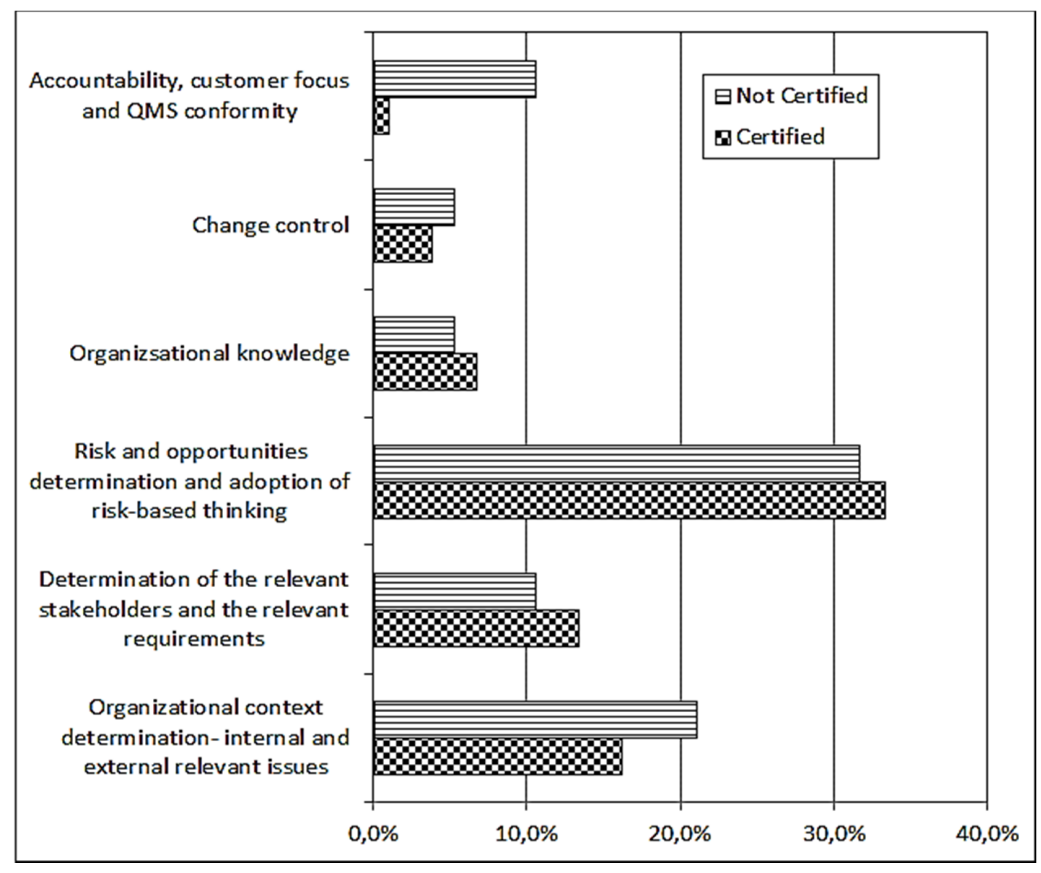

Figure 10 - Relative Distribution of the Most Often Reported Difficulties Faced (or Expected to Be Faced) During ISO 9001:2015 Implementation Process - Breakdown by Certified Organisations and Those Not Yet Certified (According to the ISO 9001:2015 Standard) (Authors Own Elaboration)

\subsection{Study on ISO 9001:2015 Motivations and Benefits}

Considering ISO 9001:2015 novelty, the investigation aimed to address if the dimensions stated in the literature for achieving successful benefits with ISO 9001 implementation remain valid with the ISO 9001:2015 edition (RQs 4.1 to 4.5). The benefits were outlined according to the literature review and yield the results listed in Table 3 (Likert scale: 1- No relevance to 5- Highly relevant). With the purpose of simplification and benchmarking two composite indicators, presented in equations 1 (for Total Internal Benefits) and 2 (for Total External Benefits) were defined based on each benefit assessed and on it internal or external relevance:

$$
\begin{aligned}
& \text { Total Internal Benefits }=\left(1 * \frac{\sum I}{8}+0,5 * \frac{\sum(I+E)}{4}+0 * \frac{\sum E}{2}\right) \\
& \text { Total External Benefits }=\left(0 * \frac{\sum I}{8}+0,5 * \frac{\sum(I+E)}{4}+1 * \frac{\sum E}{2}\right)
\end{aligned}
$$


Based on the results presented in Tab. 4 it is possible to point out that organisations perceived and rate the achievement of external benefits higher than the achievement of internal benefits (Average of 3.9 versus 3.745) upon ISO 9001:2015 implementation and certification. Also, the results suggest that organisations find "Improved awareness regarding risk and its minimisation" as the most beneficial issue attained upon ISO 9001:2015 certification (Average 4.3). Among other high rated benefits (Average 4.0) reported, one should stress the following: increased Top Management commitment, improved awareness of the stakeholders, their expectations, and requirements concerning the products and services $(\mathrm{P} \& S)$ and opportunities identification. Regarding those potential benefits rated lower by the organisations (Average lower than 3.5) the following should be mentioned: sharpen the definition of the requirements of the products and services (P\&S), cost reductions and improved integration with ISO 14001.

Table 4 - ISO 9001:2015 Benefits Summary (Authors Own Elaboration)

\begin{tabular}{|l|c|c|c|}
\hline \multicolumn{1}{|c|}{ Benefits } & $\begin{array}{c}\text { Internal (I) } \\
\text { /External }\end{array}$ & Average (1 to 5) & $\begin{array}{c}\text { Std } \\
\text { Dev. }\end{array}$ \\
\hline [B1] Alignment with business strategy & I+E & 3.9 & 1.13 \\
\hline $\begin{array}{l}\text { [B2] Increased Top Management } \\
\text { commitment }\end{array}$ & I & 4.0 & 1.15 \\
\hline $\begin{array}{l}\text { [B3] Improved accountability from the } \\
\text { processes leaders and involved } \\
\text { employees }\end{array}$ & I & 3.9 & 1.09 \\
\hline $\begin{array}{l}\text { [B4] Improved awareness of the } \\
\text { stakeholders, their expectations, and } \\
\text { requirements concerning the P\&S }\end{array}$ & E & 4.0 & 0.85 \\
\hline $\begin{array}{l}\text { [B5] Sharpen definition of the } \\
\text { requirements of P\&S }\end{array}$ & I+E & 3.4 & 1.06 \\
\hline $\begin{array}{l}\text { [B6] Improved awareness regarding risk } \\
\text { and its minimization }\end{array}$ & I+E & 4.3 & 0.83 \\
\hline [B7] Opportunities identification & I+E & 4.0 & 0.97 \\
\hline $\begin{array}{l}\text { [B8] Safeguard and access to relevant } \\
\text { knowledge }\end{array}$ & I & 3.7 & 0.93 \\
\hline $\begin{array}{l}\text { [B9] Less prescriptive and documentation } \\
\text { requirements }\end{array}$ & I & 3.6 & 1.07 \\
\hline [B10] Cost reductions & I & 3.5 & 1.40 \\
\hline [B11] Productivity improvements & I & 3.6 & 1.29 \\
\hline [B12] Increased product/service quality & Equation 1 & 3.8 & 1.18 \\
\hline [B13] Improved processes performance & $\begin{array}{l}\text { I } \\
\text { [B14] Improved integration with } \\
\text { ISO 14001 }\end{array}$ & & 1.15 \\
\hline Total Internal benefits & & & -1.9 \\
\hline
\end{tabular}




\begin{tabular}{|l|c|c|c|}
\hline \multicolumn{1}{|c|}{ Benefits } & $\begin{array}{c}\text { Internal (I) } \\
\text { /External } \mathbf{€}\end{array}$ & Average (1 to 5) & $\begin{array}{c}\text { Std } \\
\text { Dev. }\end{array}$ \\
\hline Total External benefits & Equation 2 & 3.9 & --- \\
\hline
\end{tabular}

The external/internal type of motivation, the sector of activity, the organisation size, the international business intensity, and the number of years of the certification were the dimensions used to study the factors that might influence the achievement of ISO 9001:2015 implementation and certification benefits. Tab. 5 summarises the average scores.

Table 5 - ISO 9001:2015 Dimensions That Influence Positive Results. Summary of Research Questions (RQ) Testing (Authors Own Elaboration)

\begin{tabular}{|c|c|c|}
\hline \multicolumn{3}{|c|}{$\begin{array}{l}\text { RQ4: What are the main dimensions that influence the successful ISO 9001:2015 } \\
\text { implementation and certification? }\end{array}$} \\
\hline Hypothesis & \multicolumn{2}{|c|}{ Average value } \\
\hline $\begin{array}{l}\text { RQ4.1: Does the internal/external type of } \\
\text { motivation to implement ISO 9001:2015 } \\
\text { influence the achievement of positive results? }\end{array}$ & $\begin{array}{l}\text { Mainly Internal } \\
\quad 3.7\end{array}$ & $\begin{array}{l}\text { Mainly External } \\
\quad 3.9\end{array}$ \\
\hline $\begin{array}{l}\text { RQ4.2: Does the organisational sector } \\
\text { influences the achievement of positive results } \\
\text { with ISO 9001:2015 implementation? }\end{array}$ & $\begin{array}{c}\text { Industry } \\
3.8\end{array}$ & $\begin{array}{l}\text { Commerce and Services } \\
3.9\end{array}$ \\
\hline $\begin{array}{l}\text { RQ4.3: Does the organization size influence } \\
\text { the achievement of positive results with ISO } \\
9001: 2015 \text { implementation and certification? }\end{array}$ & $\begin{array}{l}\text { Small (less than } 50 \\
\text { employees) } \\
3.9\end{array}$ & $\begin{array}{l}\text { Medium/Large (more } \\
\text { than } 50 \text { employees) } \\
3.5\end{array}$ \\
\hline $\begin{array}{l}\text { RQ4.4: Does the organization international } \\
\text { presence influence the achievement of } \\
\text { positive results with ISO 9001:2015 } \\
\text { implementation and certification? }\end{array}$ & $\begin{array}{l}\text { Small international } \\
\text { presence (less than } \\
25 \% \text { total revenue) } \\
\quad 3.8\end{array}$ & $\begin{array}{l}\text { Medium international } \\
\text { presence (more than } \\
25 \% \text { total revenue) } \\
\quad 3.5\end{array}$ \\
\hline $\begin{array}{l}\text { RQ4.5: Does the number of years of } \\
\text { certification influence the achievement of } \\
\text { positive results? }\end{array}$ & $\begin{array}{l}\text { Less than } 6 \text { years' } \\
\text { certification } \\
3.7\end{array}$ & $\begin{array}{l}\text { More than } 6 \text { years' } \\
\text { certification } \\
3.8\end{array}$ \\
\hline
\end{tabular}

To answer research questions 4.1 to 4.5 the statistical Wilcoxon signed rank test was adopted to assess the statistical relevance of the differences among each one of the benefits for the two groups. Concerning the Wilcoxon signed rank test, the solely statistical difference ascertained relates with the benefit- Access to relevant knowledge that was statistically perceived different concerning the type of motivation leading to the implementation of the ISO 9001:2015 ( $\mathrm{Z}=-2.292$; p-value $<0.05(0.022)$ ).

Supported on the summarised results listed in Tab. 4 it is possible to conclude that the perceived benefits seem to be strongly influenced by two primary dimensions: the organisation size and the international presence (highest differences). Both the activity sector where the organisation operates and the 
organisational number of years since certification seems not to impact so much on the perception of the attained benefits with ISO 9001:2015 implementation (lowest values).

The results are graphically depicted breakdown by benefit throughout Fig. 11 to 15. Tab. 6 presents information regarding the assessment of each group within each assessed dimension. On this regard, it is possible to point out that those organisations who claimed that internal motivations were the primary drivers to ISO 9001:2015 implementation systematically rate lower all the benefits when compared with the rating ascribed by those organisations who claimed external motivations. Furthermore, based on the information in Tab. 6, smaller organisations and those who reported a low international presence rate higher all the benefits attained upon ISO 9001:2015 certification.

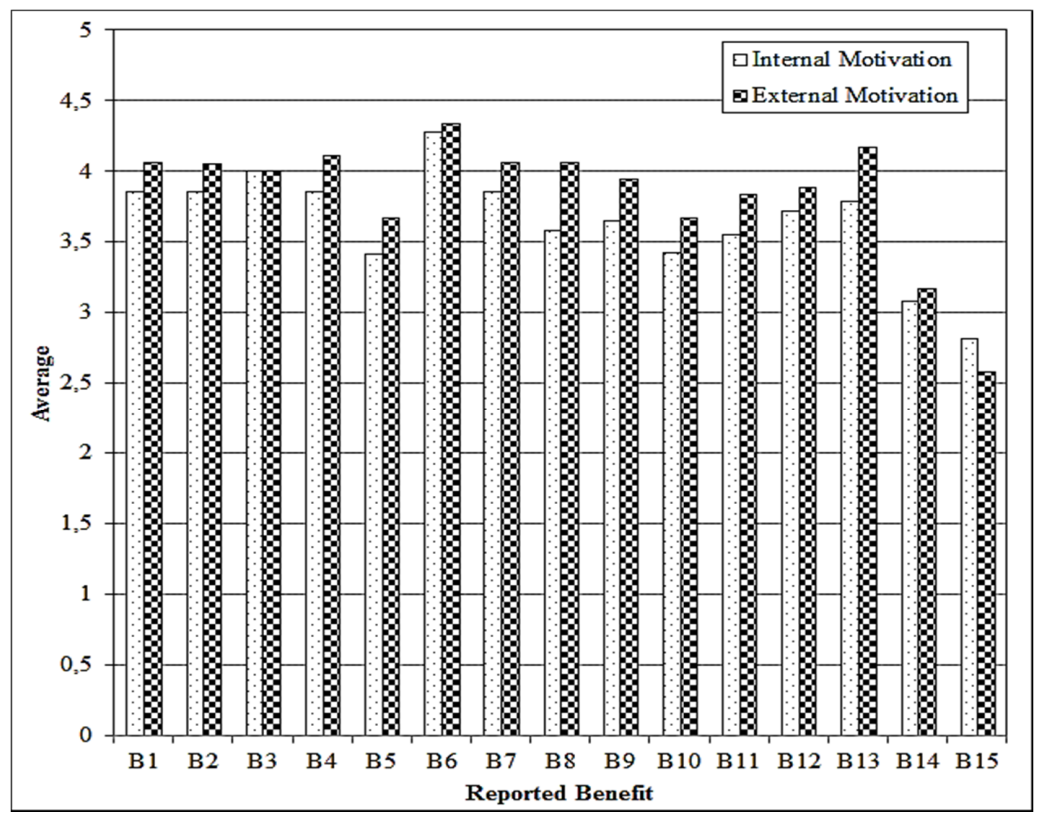

Figure 11 - Motivation Driving ISO 9001: 2015 Implementation (Authors Own Elaboration) 


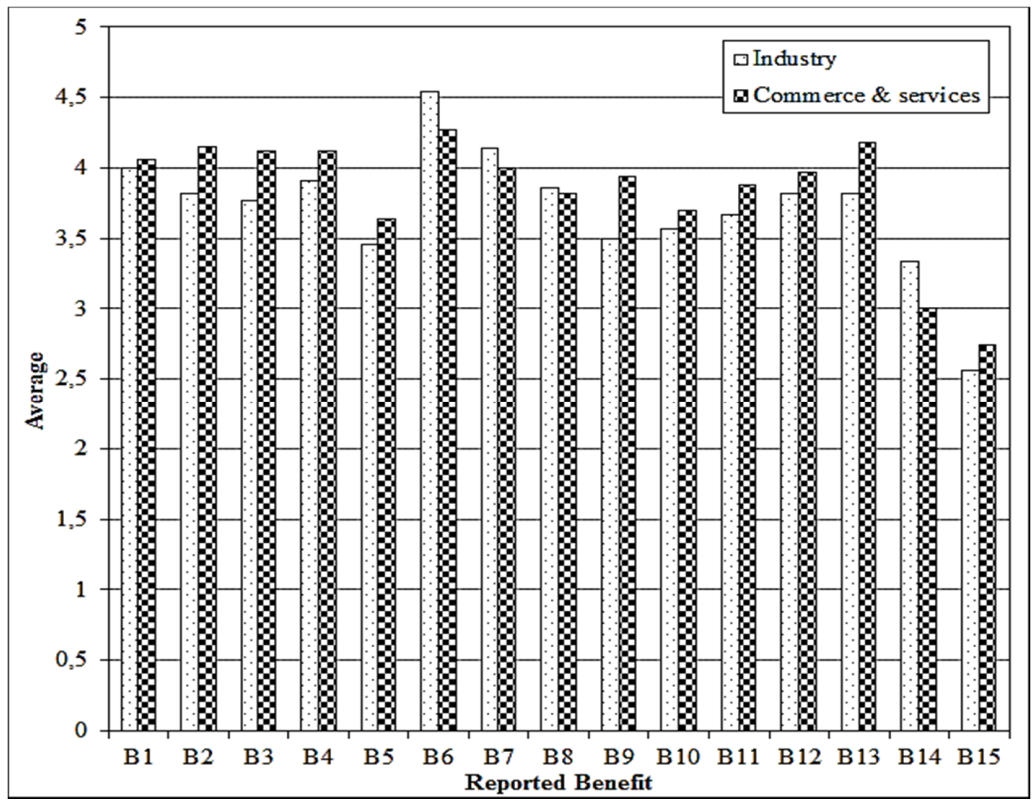

Figure 12 - Activity Sector (Authors Own Elaboration)

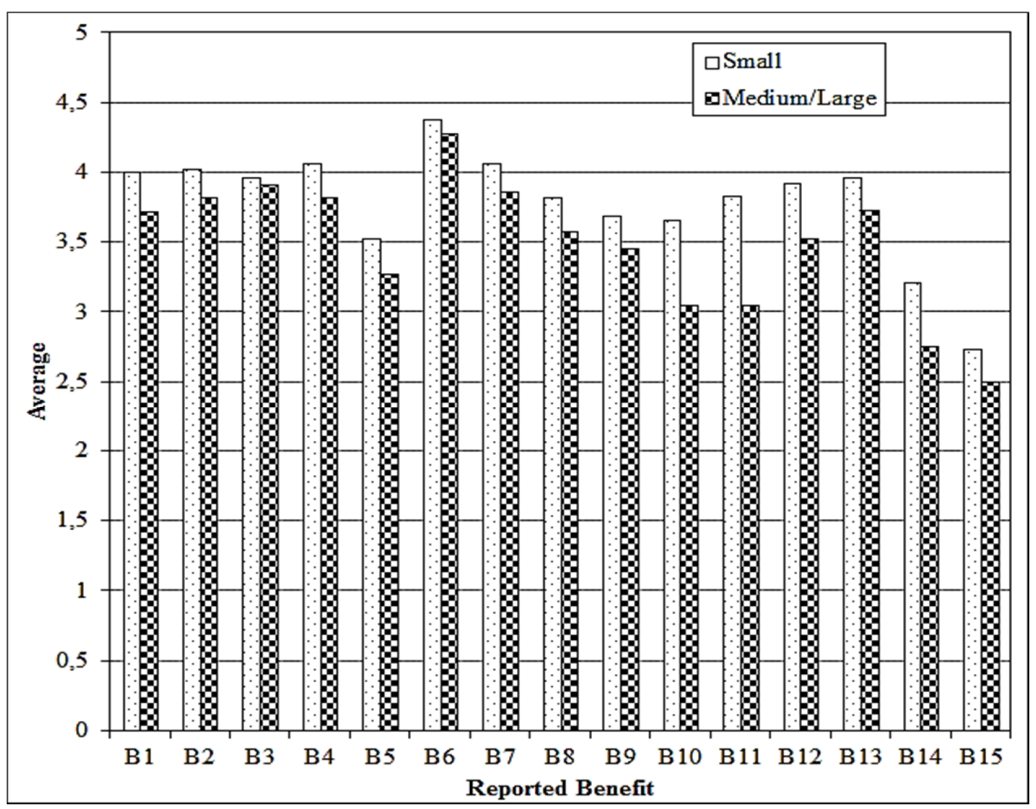

Figure 13 - Organization Dimension (Authors Own Elaboration) 


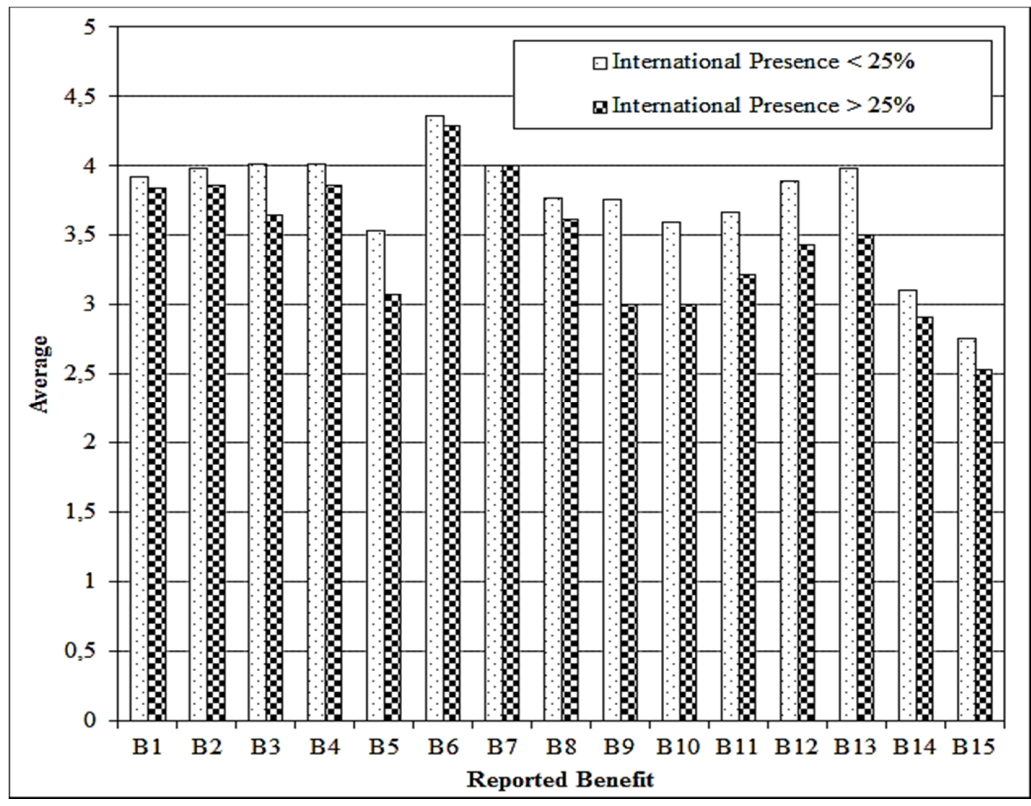

Figure 14 - International Presence (Authors Own Elaboration)

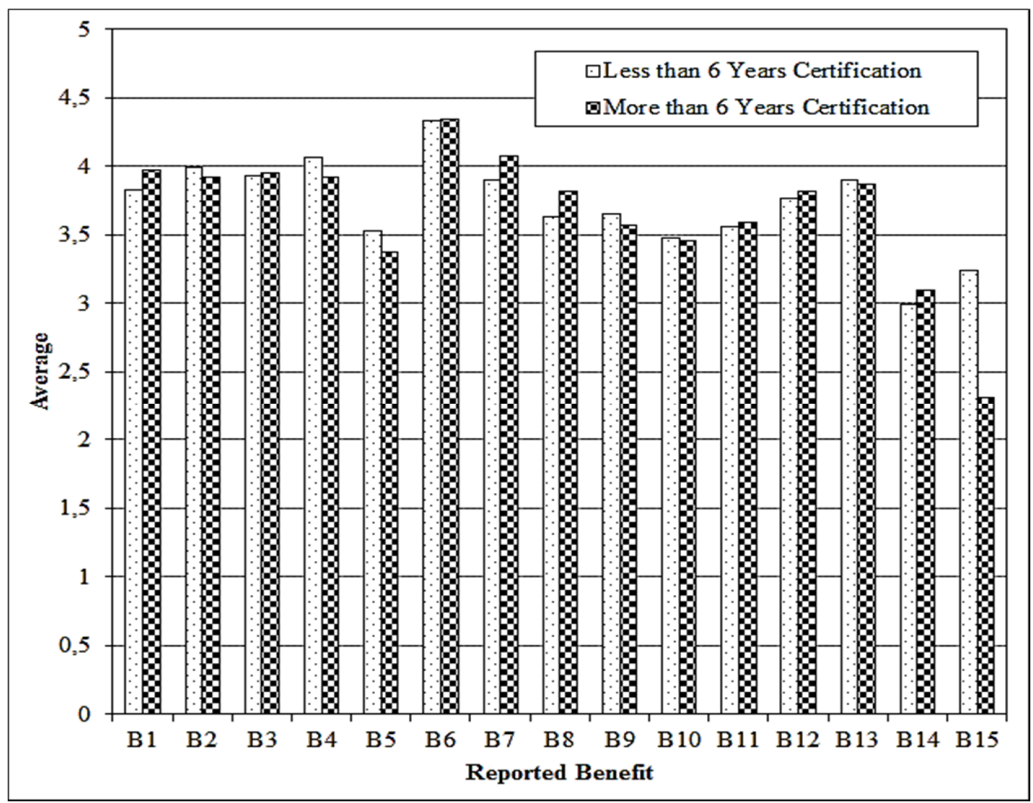

Figure 15 - The Number of Years Since the QMS First Certification (Authors Own Elaboration) 
Table 6 - Comparison between Ratings among the Groups within Dimensions (Authors Own Elaboration)

\begin{tabular}{|c|c|c|c|c|c|}
\hline & $\begin{array}{c}\text { Internal } \\
\text { vs. } \\
\text { External } \\
\text { motivation }\end{array}$ & $\begin{array}{c}\text { Industry vs. } \\
\text { Commerce \& } \\
\text { Services }\end{array}$ & $\begin{array}{c}\text { Small vs. } \\
\text { Medium/Large }\end{array}$ & $\begin{array}{c}\text { Int. Pres. } \\
\text { <25\% vs Int. } \\
\text { Pres. } \mathbf{2 5 \%}\end{array}$ & $\begin{array}{c}\text { Number of years } \\
\text { QMS certification, } \\
\text { "less than 6" vs. “6 } \\
\text { or more" }\end{array}$ \\
\hline B1 & $\downarrow$ & $\downarrow$ & $\uparrow$ & $\uparrow$ & $\downarrow$ \\
\hline B2 & $\downarrow$ & $\downarrow$ & $\uparrow$ & $\uparrow$ & $\uparrow$ \\
\hline B3 & $\downarrow$ & $\downarrow$ & $\uparrow$ & $\uparrow$ & $\downarrow$ \\
\hline B4 & $\downarrow$ & $\downarrow$ & $\uparrow$ & $\uparrow$ & $\uparrow$ \\
\hline B5 & $\downarrow$ & $\downarrow$ & $\uparrow$ & $\uparrow$ & $\downarrow$ \\
\hline B6 & $\downarrow$ & $\uparrow$ & $\uparrow$ & $\uparrow$ & $\downarrow$ \\
\hline B7 & $\downarrow$ & $\uparrow$ & $\uparrow$ & $\rightarrow$ & $\downarrow$ \\
\hline B8 & $\downarrow$ & $\uparrow$ & $\uparrow$ & $\uparrow$ & $\uparrow$ \\
\hline B9 & $\downarrow$ & $\downarrow$ & $\uparrow$ & $\uparrow$ & $\uparrow$ \\
\hline B10 & $\downarrow$ & $\downarrow$ & $\uparrow$ & $\uparrow$ & $\downarrow$ \\
\hline B11 & $\downarrow$ & $\downarrow$ & $\uparrow$ & $\uparrow$ & $\downarrow$ \\
\hline B12 & $\downarrow$ & $\downarrow$ & $\uparrow$ & $\uparrow$ & $\uparrow$ \\
\hline B13 & $\downarrow$ & $\downarrow$ & $\uparrow$ & $\uparrow$ & $\downarrow$ \\
\hline B14 & $\downarrow$ & $\uparrow$ & $\uparrow$ & $\uparrow$ & $\downarrow$ \\
\hline
\end{tabular}

\section{CONCLUSION}

Halfway through the transition period, concerning ISO 9001:2015 transition and certification $19 \%$ of the respondents are already certified to ISO 9001:2015 and, from this group, 58\% made only minor adjustments to their QMS, while $37 \%$ made a substantial reformulation. From the remaining $81 \%$, $46 \%$ plan to complete the process in 2017 and $52 \%$ in $2018 ; 39 \%$ are still studying the ISO 9001:2015 International Standard or lacked time to do it (36\%). The rate of transition to ISO 9001:2015 increased 64\% in the first four months of 2017 when compared to 2016b (Conclusions concerning RQ1).

Relating to RQ2, "what are the main benefits achieved with ISO 9001:2015 implementation and certification" (respondents: ISO 9001:2015 certified organisations) the results are Risk and opportunities determination and adoption of risk-based thinking" (67\%), followed by "Organizational context determination - internal and external relevant issues" (36\%) and the "Determination of the relevant interested parties and the relevant requirements" $(29 \%)$.

To statistically assess if a significant difference does exist among the perceptions expressed by the CEOs and those expressed by Quality Managers (RQ 2.1) the 
Chi-Square statistical test was applied. The p-value (0.619) suggests that based on the collected results there is no evidence of statistical differences between the two groups, however, due to the CEO's small sample size, this should be further investigated.

Following with RQ3, "the new ISO 9001:2015 themes that the organisation considers most difficult to successfully implement (respondents: ISO 9001:2015 certified organisations) are also "Risk and opportunities determination and adoption of risk-based thinking" (57\%), "Organizational context determination internal and external relevant issues" (31\%) and the "Determination of the relevant interested parties and the relevant requirements" (24\%). The Chi-Square statistical test was adopted to ascertain if there are statistical differences between the distributions of the two groups (RQ 3.1). The p-value suggests that based upon the collected results there is no evidence of statistical differences between the two groups, i.e., the expected difficulties to be faced during the implementation process are in fact those that are experienced by the companies that proceeded with the transition.

\section{Table 7 - Summary of RQ 4.1 To 4.5 (Authors Own Elaboration)}

\begin{tabular}{|l|l|}
\hline \multicolumn{1}{|c|}{ Research Question (RQ) } & \multicolumn{1}{|c|}{ Results of hypotheses testing } \\
\hline $\begin{array}{l}\text { RQ 4.1: Does the internal/external } \\
\text { type of motivation to implement ISO } \\
9001: 2015 \text { influence the achievement } \\
\text { of positive results? }\end{array}$ & $\begin{array}{l}\text { The statistical Wilcoxon signed rank test was adopted } \\
\text { to assess the statistical relevance of the differences } \\
\text { among each one of the benefits between the two } \\
\text { groups. Concerning the Wilcoxon signed rank test, the } \\
\text { solely statistical difference ascertained relates with the } \\
\text { benefit "Access to relevant knowledge" that was } \\
\text { statistically perceived different concerning the type of } \\
\text { motivation leading to the implementation of the ISO } \\
9001: 2015 \text { (Z }=2.292 ; \text { p-value }<0.05 \text { (0.022)). } \\
\text { However, based on the graphical analysis presented in } \\
\text { Figure 11 it is possible to hint that those organisations } \\
\text { who claimed that internal motivations were the } \\
\text { primary drivers to ISO 9001:2015 implementation } \\
\text { systematically rate lower all the benefits when } \\
\text { compared with the rating ascribed by those } \\
\text { organisations who claimed external motivations. }\end{array}$ \\
\hline $\begin{array}{l}\text { RQ 4.2: Does the Organisational } \\
\text { sector influences the achievement of } \\
\text { positive results with ISO }\end{array}$ & $\begin{array}{l}\text { Supported on the summarised results listed in Table 5 } \\
\text { it is possible to conclude that the perceived benefits } \\
\text { seem to be strongly influenced by two primary } \\
\text { dimensions: the organisation size and the international } \\
\text { presence (highest differences). Both the activity sector } \\
\text { where the organisation operates and the number of } \\
\text { certification years seems not to impact so much on the } \\
\text { perception of the attained benefits upon ISO } \\
9001: 2015 \text { implementation (lowest differences). }\end{array}$ \\
\hline $\begin{array}{l}\text { RQ 4.3: Does the organisation size } \\
\text { influence the achievement of positive } \\
\text { results with ISO 9001:2015 }\end{array}$ & $\begin{array}{l}\text { Supported by the summarised results listed in Table 5 } \\
\text { it is possible to conclude that the perceived benefits } \\
\text { seem to be strongly influenced by two primary }\end{array}$ \\
\hline
\end{tabular}




\begin{tabular}{|c|c|}
\hline Research Question (RQ) & Results of hypotheses testing \\
\hline implementation and certification? & \multirow{3}{*}{$\begin{array}{l}\text { dimensions: the organisation size and the international } \\
\text { presence (highest differences). Both the activity sector } \\
\text { where the organisation operates and the number of } \\
\text { certification years seems not to impact so much on the } \\
\text { perception of the attained benefits upon ISO } \\
9001: 2015 \text { implementation (lowest differences). }\end{array}$} \\
\hline $\begin{array}{l}\text { RQ 4.4: Does the organisation } \\
\text { international presence intensity impact } \\
\text { on the achievement of positive results } \\
\text { with ISO 9001:2015 implementation } \\
\text { and certification? }\end{array}$ & \\
\hline $\begin{array}{l}\text { R Q4.5: Does the number of years of } \\
\text { QMS certification influences the } \\
\text { achievement of positive results? }\end{array}$ & \\
\hline
\end{tabular}

As a conclusion, based on the respondents' responses, it is possible to hint that organizations who claimed that external motivations were the primary drivers to ISO 9001:2015 implementation systematically rate higher all the benefits when compared with the rating ascribed by those organizations who claimed internal motivations, contesting some previous research still based on ISO 9001:2008. Moreover, it is possible to conclude that the perceived benefits from ISO 9001:2015 implementation and certification seem to be strongly influenced by two primary dimensions: the (smaller) organisation size and the (lesser) international presence.

With more than 1 million ISO 9001 certified organisation from all sectors of activity, worldwide, the transition/certification for ISO 9001:2015 is a highly relevant issue both for organisations and their professionals and academics. ISO 9001:2015 aims for the consistent delivery of quality products and services and the fulfilment of the applicable requirements. It also focuses on business and quality approaches that are relevant to the organisations enduring success. It is indeed a highly valuable research topic to observe what will be the successful transition rate for ISO 9001:2015, and if the motivations, critical dimensions, benefits, and obstacles, are consistent with this investigation results. However, due to ISO 9001:2015 implementation novelty, the results of this investigation should be subject to future confirmation and possibly extended to other countries. It should also be acknowledged that the survey was based on the perceptions of the organisation's Managers and there is a risk of some potential response bias.

\section{ACKNOWLEDGEMENTS}

The authors would like to acknowledge the contribution of the respondents. CIDEM Centro de Investigação e Desenvolvimento em Engenharia Mecânica R\&D unit is funded by the FCT - Portuguese Foundation for the Development of Science and Technology, Ministry of Science, Technology, and Higher Education, under the Project UID/EMS/0615/2016. This study had the financial support of FCT Fundação para a Ciência e Tecnologia of Portugal under the project UID/CEC/00319/2013. Pedro Domingues is supported by FCT Post-Doc Grant Reference SFRH/BPD/103322/2014. 


\section{REFERENCES}

Anttila, J. and Jussila, K., 2017. ISO 9001:2015- a questionable reform. What should the implementing organisations understand and do?. Total Quality Management and Business Excellence, [e-journal] 28(9-10), pp.1090-1105. http://dx.doi.org/10.1080/14783363.2017.1309119.

APCER, 2017. APCER. [online] Porto. Available at: $<$ https://www.apcergroup.com/portugal/index.php/en/> [Acessed 01 April 2017].

Armstrong, J.S. and Overton, T.S., 1977. Estimating Nonresponse Bias in Mail Surveys. Journal of Marketing, 14(3), pp.396-402.

Benner, M. and Veloso, F., 2008. ISO 9000 practices and financial performance: A technology coherence perspective. Journal of Operations Management, [ejournal] 26(5), pp.611-629. http://dx.doi.org/10.1016/j.jom.2007.10.005.

Bernard, A.B. and Jensen, J.B., 1999. Exceptional exporter performance: Cause, effect, or both?. Journal of International Economics, [e-journal] 47(1), pp.1-25. http://dx.doi.org/10.1016/S0022-1996(98)00027-0.

Bernardo, M., Simón, A., Tarí, J. and Molina-Azorín, J., 2015. Benefits of management systems integration: A literature review. Journal of Cleaner Production, [e-journal] 94(1), pp.260-267. http://dx.doi.org/10.1016/j.jclepro.2015.01.075.

Bhuiyan, N. and Alam, N., 2010. An investigation into issues related to the latest version of ISO 9000. Total Quality Management and Business Excellence, [ejournal] 16(2), pp.199-213. http://dx.doi.org/10.1080/14783360500054343.

Boiral, O. and Amara, N., 2009. Paradoxes of ISO 9000 performance: A configurational approach. Quality Management Journal, [e-journal] 16(3), pp.3660. http://dx.doi.org/10.1080/10686967.2009.11918240.

Boiral, O. and Roy, M., 2007. ISO 9000: Integration rationales and organizational impacts. International Journal of Operations and Production Management, [e-journal] 27(2), pp.226-247. http://dx.doi.org/10.1108/01443570710.

Briscoe, J., Fawcett, S. and Todd, R., 2005. The implementation and impact of ISO 9000 among small manufacturing enterprises. Journal of Small Business Management, [e-journal] 43(3), pp.309-330. http://dx.doi.org/10.1111/j.1540627X.2005.00139.x.

Calvo, M., Redondo, E., Mora, A. and Cristóbal, R., 2016. Sistemas de gestión de la calidad: un estudio en empresas del sur de España y norte de Marruecos. European Research on Management and Business Economics, [e-journal] 22(1), pp.8-16. https://doi.org/10.1016/j.iedee.2015.10.001. 
Casadesus, M. and Karapetrovic, S., 2005. Has ISO 9000 lost some of its lustre? A longitudinal impact study. International Journal of Operations \& Production Management, [e-journal] 25(6), pp.580-596. http://dx.doi.org/ 10.1108/01443570510.

Casadesus, M., Karapetrovic, S. and Heras, I., 2004. Beneficios y costes de la implantación de la normativa de calidad ISO 9000: Un estudio comparativo (1998-2002). Revista de Economía y Empresa, 21(5), pp.57-74.

Castillo-Peces, C., Mercado-Idoeta, C., Prado-Roman, M. and Castillo-Feito, C., 2017. The influence of motivations and other factors on the results of implementing ISO 9001 standards. European Research on Management and Business Economics, [e-journal] 24(1), pp.33-41. http://dx.doi.org/10.1016/j.iedeen.2017.02.002.

Chang, D. and Lo, L., 2005. Measuring the relative efficiency of a firm's ability to achieve organizational benefits after ISO certification. Total Quality Management and Business Excellence, [e-journal] 16(1), pp.57-69. http://dx.doi.org/10.1080/1478336042000309866.

Chen, C-K., Anchecta, K., Lee, Y-D. and Dahlgaard, J.J., 2016. A stepwise ISObased TQM implementation approach using ISO 9001:2015. Management and Production Engineering Review, [e-journal] 7(4), pp. 65-75. http://dx.doi.org/10.1515/mper-2016-0037.

Chiarini, A., 2011. Integrating lean thinking into ISO 9001: a first guideline. International Journal of Lean Six Sigma, [e-journal] 2(2), pp.96-117. http://dx.doi.org/10.1108/204014611111.

Corbett, C., Montes, M. and Kirsch, D., 2005. The financial impact of ISO 9000 certification in the United States: An empirical analysis. Management Science, [e-journal] 51(7), pp.1046-1059. http://dx.doi.org/10.1287/mnsc.1040.0358.

Dey, P., 2010. How to complement ISO 9001:2000 with Six Sigma. iSixSigma LLC, [online]. Available at: < http://isixsigma.com/library/content/c020211a.asp> [Accessed 02 January 2017].

Dick, G., Heras, I. and Casadesús, M., 2008. Shedding light on causation between ISO9001 and improve business performance. International Journal of Operations and Production Management, [e-journal] 28(7), pp.687-708. http://dx.doi.org/10.1108/01443570810.

Domingues J.P.T., Fonseca L., Sampaio P. and Arezes, P.M., 2016. Integrated versus non-integrated perspectives of auditors concerning the new ISO 9001 revision. In: IEEE, International Conference on Industrial Engineering and Engineering Management (IEEM). Bali, Indonesia, 4-7 December 2016. IEEE. http://dx.doi.org/10.1109/IEEM.2016.7798000. 
Ellis, P.D., Davies, H. and Wong, A.H.-K., 2011. Export intensity and marketing in transition economies: Evidence from China. Industrial Marketing Management, [e-journal] 40(4), pp.593-602. http://dx.doi.org/ 10.1016/j.indmarman.2010.10.003.

Fonseca, L.M., 2015a. From Quality gurus and TQM to ISO 9001:2015: a review of several quality paths. International Journal for Quality Research, 9(1), pp.167-180.

Fonseca, L.M., 2015b. Relationship between ISO 9001 certification maturity and EFQM business excellence model results. Quality Innovation Prosperity, [ejournal] 19(1), pp.85-102. http://dx.doi.org/10.12776/QIP.V19I1.556.

Fonseca, L.M. and Domingues, J.P.T., 2017. ISO 9001:2015- Quality, Management, and Value. International Journal for Quality Research, [e-journal] 11(1), pp.149-158. http://dx.doi.org/10.18421/IJQR11.01-09.

Fonseca, L.M. and Lima, V.M., 2015. Impact of supplier management strategies on the organizational performance of ISO 9001 certified organizations. Quality Innovation Prosperity, [e-journal] 19(2), pp.32-54. http://dx.doi.org/10.12776/QIP.V19I2.592.

Fonseca, L.M., Domingues, J.P. and Sá, J., 2017. Leading Quality in the 21st Century: Profiles of Quality and Organizational Excellence Managers. Quality Access to Success, 18(161), pp-34-38.

Fonseca, L.M., Domingues, J.P., Machado, P.B. and Calderón, M., 2017. Management System Certification Benefits: Where Do We Stand?. Journal of Industrial Engineering and Management, [e-journal] 10(3), pp. 476-494. http://dx.doi.org/10.3926/jiem.2350.

Fotopoulos, C. and Psomas, E., 2010. ISO 9001:2000 implementation in the Greek food sector. The TQM Journal, [e-journal] 22(2), pp.129-142. http://dx.doi.org/10.1108/175427310110.

Gustafsson, R., Klefsjo, B., Berggren, E. and Granfors, U., 2001. Experiences from implementing ISO 9000 in small enterprises: A study of Swedish organizations. The TQM Magazine, [e-journal] 13(4), pp.232-246. http://dx.doi.org/10.1016/j.indmarman.2010.10.003.

Heras, I. and Arana, G., 2006. A Delphi study on motivation for ISO 9000 and EFQM. International Journal of Quality and Reliability Management, [e-journal] 23(7), pp.807-827. http://dx.doi.org/10.1108/02656710610.

Heras, I., Dick, G. and Casadesus, M., 2002. ISO 9000 registration's impact on sales and profitability. International Journal of Quality and Reliability Management, [e-journal] 19(6), pp.774-791. http://dx.doi.org/10.1108/02656710210. 
IAF, 2017. IAF_Resolution_201713/522. [online] Canada: International Accreditation Forum. Available at: $<$ https://www.iaf.nu/articles/IAF_Resolution_201713/522> [Acessed 01 February 2018].

Ismyrlis, V. and Moschidis, O., 2015. The use of quality management systems, tools, and techniques in ISO 9001: 2008 certified companies with multidimensional statistics: The Greek case. Total Quality Management and Business Excellence, [e-journal] 26(5-6), pp.497-514. http://dx.doi.org/10.1080/14783363.2013.856543.

ISO, 2008. ISO 9001 quality management systems- requirements. Geneva: International Organization for Standardization.

ISO, 2015. ISO 9001 quality management systems- requirements. Geneva: International Organization for Standardization.

ISO, 2017. ISO Survey 2016. [online] Geneva: International Organization for Standardization. Available at: <http//www.iso.org > [Acessed 01 February 2018].

Karapetrovic, S., Fa, M. and Heras, I., 2010. What happened to the ISO 9000 lustre? An eight-year study. Total Quality Management and Business Excellence, [e-journal] 21(3), pp.245-267. http://dx.doi.org/10.1080/14783360903553149.

Lee, P., To, W. and Yu, B., 2009. The implementation and performance outcomes of ISO 9000 in service organizations: An empirical taxonomy. International Journal of Quality and Reliability Management, [e-journal] 26(7), pp.646-662. http://dx.doi.org/10.1108/02656710910.

Ling-Yee, L., 2004. An examination of the foreign market knowledge of exporting firms based in the People's Republic of China: Its determinants and effect on export intensity. Industrial Marketing Management, [e-journal] 33(7), pp.561-572. http://dx.doi.org/10.1016/j.indmarman.2004.01.001.

Llopis, J. and Tari, J., 2003. The importance of internal aspects in quality improvement. International Journal of Quality \& Reliability Management, [ejournal] 20(3), pp.304-324. http://dx.doi.org/10.1108/02656710310.

Lupan, R., Bacivarof, I.C., Kobi, A. and Robledo, C., 2005. A relationship between Six Sigma and ISO 9001:2000. Quality Engineering, [e-journal] 17(4), pp.719-725. http://dx.doi.org/10.1080/08982110500251329.

Marques, P.A., Meyrelles, P.M., Saraiva, P.M. and Frazão-Guerreiro, F.J., 2016. Integrating Lean Six Sigma with ISO 9001:2015. In: IEEE, International Conference on Industrial Engineering and Engineering Management (IEEM). Bali, Indonesia, 4-7 December $2016 . \quad$ IEEE. http://dx.doi.org/10.1109/IEEM.2016.7798006. 
Martínez-Costa, M. and Martínez-Lorente, A., 2003. Effects of ISO 9000 certification on firms' performance: A vision from the market. Total Quality Management and Business Excellence, [e-journal] 14(10), pp.1179-1191. http://dx.doi.org/10.1080/1478336032000107735.

Martínez-Costa, M. and Martínez-Lorente, A., 2007. A triple analysis of ISO 9000 effects on company performance. International Journal of Productivity and Performance Management, [e-journal] 56(5/6), pp.484-499. http://dx.doi.org/10.1108/17410400710.

Martínez-Costa, M., Choi, T., Martínez, J. and Martínez-Lorente, A., 2009. ISO 9000:1994, ISO 9001:2000 and TQM: The performance debate revisited. Journal of Operations Management, [e-journal] 27(6), pp.495-511. http://dx.doi.org/10.1016/j.jom.2009.04.002.

Martínez-Costa, M., Martínez-Lorente, A. and Choi, T., 2008. Simultaneous consideration of TQM and ISO 9000 on performance and motivation: An empirical study of Spanish companies. International Journal of Production Economics, [e-journal] 113(1), pp.23-39. http://dx.doi.org/10.1016/j.ijpe.2007.02.046 .

Micklewright, M., 2010. Lean ISO 9001: Adding Spark to Your ISO 9001 QMS and Sustainability to Your Lean Efforts. Milwaukee, WI: American Society for Quality.

Pekovic, S., 2010. The determinants of ISO 9000 certification: A comparison of the manufacturing and service sectors. Journal of Economic Issues, [e-journal] 54(4), pp.895-914. http://dx.doi.org/10.2753/JEI0021-3624440403.

Pfeifer, T., Reissiger, W. and Canales, C., 2004. Integrating Six Sigma with quality management systems. The TQM Magazine, [e-journal] 16(4), pp.241-249. http://dx.doi.org/10.1108/09544780410.

Poksinska, B. and Dahlgaard, J., 2003. ISO 9001:2000- the emperor's new clothes?. European Quality, 10(3), pp.58-69.

Prado, C., Castillo, C., Mercado, C. and Soto, F., 2013. Los resultados de la implantación de la norma en 9100 en el sector aeroespacial espanol. Revista Galega de Economía, 22(1), pp.151-176.

Prajogo, D., 2011. The role of firms motives in affecting the outcomes of ISO 9000 adoption. International Journal Operations and Production Management, [e-journal] 31(1), pp.78-100. http://dx.doi.org/10.1108/014435711110.

Psomas, E., 2013. The effectiveness of the ISO 9001 quality management system in service companies. Total Quality Management and Business Excellence, [ejournal] 24(7-8), pp.769-781. http://dx.doi.org/10.1080/14783363.2013.791099. 
Rybskia, C., Jochemb, R. and Homma. L., 2017. Empirical study on status of preparation for ISO 9001:2015. Total Quality Management and Business Excellence, [e-journal] 28(9-10), http://dx.doi.org/10.1080/14783363.2017.1303886.

Sampaio, P., Saraiva, P. and Rodrigues, A., 2009. ISO 9001 certification research: questions, answers and approaches. International Journal of Quality and Reliability Management, [e-journal] 26(1), pp.38-58. http://dx.doi.org/10.1108/02656710910.

Sharma, D., 2005. The association between ISO 9000 certification and financial performance. International Journal of Accounting, [e-journal] 40(2), pp.151-172. http://dx.doi.org/10.1016/j.intacc.2005.01.011.

Tari, J., Molina-Azorin, J. and Heras, I., 2012. Benefits of ISO 9001 and ISO 14001 standards: A literature review. Journal of Industrial Engineering Management, [e-journal] 5(2), pp.297-332. http://dx.doi.org/10.3926/jiem.488.

Terlaak, A. and King, A., 2006. The effect of certification with the ISO 9000 Quality Management Standard: A signalling approach. Journal of Economics Behavior and Organization, [e-journal] 60(4), pp.579-602. http://dx.doi.org/10.1016/j.jebo.2004.09.012.

Terziovski, M. and Power, D., 2007. Increasing ISO 9000 certification benefits: A continuous improvement approach. International Journal of Quality and Reliability Management, [e-journal] 24(2), pp.141-163. http://dx.doi.org/10.1108/02656710710.

Terziovski, M., Power, D. and Sohal, A., 2003. The longitudinal effects of the ISO 9000 certification process on business performance. European Journal of Operational Research, [e-journal] 146(3), pp.580-595. http://dx.doi.org/10.1016/S0377-2217(02)00252-7.

Wahid, R. and Corner, J., 2009. Critical success factors and improvements in ISO 9000 maintenance. International Journal of Quality and Reliability Management, [e-journal] 26(9), pp.881-893. http://dx.doi.org/10.1108/02656710910.

Willar, D., Coffey, V. and Trigunarsyah, B., 2015. Examining the implementation of ISO 9001 in Indonesian construction companies. The TQM Journal, [e-journal] 27(1), pp.94-107. http://dx.doi.org/10.1108/TQM-08-20120060 .

Wilson, J.P., Walsh, M.A.T. and Needy, K.L., 2015. An examination of the economic benefits of ISO 9000 and the Baldrige Award. Engineering Management Journal, [e-journal] 15(4), pp.3-10. http://dx.doi.org/10.1080/10429247.2003.11415220. 
Zimon, D., Gajewska, T. and Bednárová, L., 2016. Influence of Quality Management System on Improving Process in Small and Medium--Sized Organizations. Quality - Access to Success, 17(155), pp.68-69.

\section{ABOUT AUTHORS}

Luis Miguel Ciravegna Martins da Fonseca - professor at Instituto Superior de Engenharia do Porto (ISEP), School of Engineering, Polytechnic Institute of Porto, Portugal, and a researcher at the Center for Research and Development in Mechanical Engineering in Porto. An ASQ fellow, he holds a doctorate in management from Lisbon University Institute in Portugal, and an electrical engineering degree from Porto University, e-mail: 1mf@isep.ipp.pt. Author's ORCID: http://orcid.org/0000-0001-5668-0656.

José Pedro Domingues - received the Bachelor degree in Chemistry (1996), the MSc Degree in Textile Environmental Chemistry (2001) and a PhD Degree in Industrial Engineering and Systems (2013) all of them from the University of Minho. He is an invited professor at ISEP - Porto School of Engineering and researcher at the University of Minho in Braga, Portugal, e-mail: jpd@isep.ipp.pt. Author's ORCID: http://orcid.org/0000-0003-1406-4905.

(C) 2018 by the authors. Submitted for possible open access publication under the terms and conditions of the Creative Commons Attribution (CC-BY) license (http://creativecommons.org/licenses/by/4.0/). 